\section{Relationship Between Spiritual Intelligence with Resilience in Teenagers Born in Poor Families}

Chelsie Ireine Finka; Berta Esti Ari Prasetya

Universitas Kristen Satya Wacana Salatiga

e-mail: chelsieiren@gmail.com
Journal PSIKODIMENSIA

Volume 17, No. 2, Juli - Desember 2018

ISSN cetak : 1411-6073

ISSN online : 2579-6321

DOI 10.24167/psidim.v17i2.1533

\begin{abstract}
This research is aimed at understanding relationship between spiritual intelligence and resilience of teenagers born in poor family in Jongin Village, Tolitoli Regency, Central Sulawesi. There are 39 participants in this research, and data collecting technique uses accidental sampling technique. Resilience variable is measured with resilience scale adapted from Resilience Quotation (RQ) and Spiritual Intelligence scale is measured with scale of Spiritual Intelligence Self-Report Inventory (SISRI-24). The data is analyzed with correlation technique of Product Moment Pearson. Correlation coefficient is $r=0.654$ ( $p$ $<0,01)$, so it can be concluded that there is positive relationship and very significance between spiritual intelligence and resilience of teenagers born in poor family in Jongin Village, Tolitoli Regency, Central Sulawesi. The higher spiritual intelligence, the higher resilience will be; and the lower spiritual intelligence, the lower resilience will be.
\end{abstract}

Keywords: resilience, spiritual intelligence, teenager

\section{PENDAHULUAN}

Keluarga merupakan unit terkecil dalam masyarakat. Keluarga merupakan tempat pertama individu belajar banyak hal, baik itu secara verbal maupun nonverbal. Keluarga adalah sekumpulan orang yang dihubungkan oleh ikatan perkawinan, adopsi, kelahiran yang bertujuan menciptakan dan mempertahankan budaya yang umum, meningkatkan perkembangan fisik, mental, emosional dan sosial diri tiap anggota keluarga. Dalam keluarga pastinya terdapat satu atau lebih individu yang merupakan seorang ayah, ibu, dan anak. Keluarga dapat dibedakan berdasarkan status ekonominya.

Keluarga dapat dibedakan berdasarkan status sosial mereka dalam masyarakat. Status sosial ekonomi adalah kedudukan atau posisi seseorang dalam masyarakat. Status sosial ekonomi adalah gambaran tentang keadaan seseorang atau suatu masyarakat yang ditinjau dari segi sosial ekonomi, gambaran itu seperti tingkat pendidikan, pendapatan dan sebagainya. Status ekonomi kemungkinan besar merupakan pembentuk gaya hidup keluarga. Pendapatan keluarga memadai akan menunjang tumbuh kembang anak.

Status ekonomi adalah kedudukan seseorang atau keluarga di masyarakat berdasarkan pendapatan per bulan. Status ekonomi dapat dilihat dari pendapatan yang disesuaikan dengan harga barang pokok (Kartono, 2006).

Kemiskinan adalah kondisi
keterbatasan kemampuan untuk
memenuhi kebutuhan hidup secara layak
seperti keterbatasan dalam pendapatan,
keterampilan, kondisi kesehatan,
penguasaan aset ekonomi, ataupun akses
informasi. Pengukuran ini bersifat
materi atau pendekatan moneter.
Pengukuran dengan pendekatan moneter
dapat dilakukan dengan menggunakan
data pengeluaran sebagai pendekatan


pendapatan rumah tangga. Kemudian data pengeluaran ini diperbandingkan dengan suatu batas nilai tukar rupiah yang diperlukan untuk memenuhi kebutuhan hidup minimum. Batas ini sering disebut sebagai garis kemiskinan. Penduduk yang pengeluarannya lebih kecil daripada garis kemiskinan ini disebut penduduk miskin. Pemerintah menggunakan garis kemiskinan berdasarkan ukuran dari BPS yang dihitung berdasarkan data Survei SosialEkonomi Nasional (SUSENAS). Di Indonesia, pada tahun 2017, pendataan yang dilakukan oleh Badan Pusat Statistik Indonesia mendapatkan hasil bahwa pada bulan September 2017, jumlah penduduk miskin (penduduk dengan pengeluaran per kapita per bulan di bawah Garis Kemiskinan) di Indonesia mencapai 26,58 juta orang (10,12 \%), berkurang sebesar 1,19 juta orang dibandingkan dengan kondisi Maret 2017 yang sebesar 27,77 juta orang $(10,64 \%)$.

Salah satunya di desa Jongin Kabupaten Tolitoli, Sulawesi Tengah. Di desa tersebut terdapat 68 kepala keluarga yang kebanyakan merupakan masyarakat asli suku pedalaman yang masih banyak tinggal di pegunungan. Penduduk di desa tersebut mayoritas bergantung pada hasil alam dan masih sering menerima bantuan dari pemerintah maupun dari orang-orang yang berbaik hati untuk memberikan bantuan. Mayoritas anak-anak di desa tersebut hanya bersekolah sampai pada jenjang SMP karena tidak memiliki biaya untuk melanjutkan sekolah, namun ada beberapa anak yang disekolahkan oleh orang-orang yang hidup berkecukupan sehingga bisa meneruskan pendidikan sampai jenjang yang tinggi. Anak-anak yang masih SDpun hanya memiliki 1 buku tulis untuk semua mata pelajaran dan tidak menggunakan sepatu. Di desa tersebut kebanyakan rumahnya hanya terbuat dari papan dan berukuran sangat kecil bahkan untuk kamar mandi dan toiletnyapun terpisah cukup jauh dari rumah serta dipakai untuk dua atau tiga kepada keluarga secara bergantian.

Kemiskinan di Indonesia merupakan faktor risiko yang memiliki dampak cenderung berkepanjangan dan kompleks. Dampak kemiskinan yang berkepanjangan ditunjukkan dengan situasi-situasi yang secara kontinu dihadapi oleh individu, yang mengakibatkan kompleksitas dampak kemiskinan tersebut akan semakin menyebar ke berbagai dimensi.

Remaja merupakan salah satu periode dalam perkembangan anak. Kata remaja (adolescence) berasal dari kata adolescere (Latin) yang berarti tumbuh ke arah kematangan. Istilah kematangan di sini meliputi kematangan fisik maupun sosial psikologis. Remaja menginginkan teman yang mempunyai minat dan nilai-nilai yang sama, yang dapat mengerti dan membuatnya merasa aman, sehingga remaja dapat mempercayakan masalah-masalah dan membahas hal-hal yang tidak dapat dibicarakannya dengan orang tua maupun guru (Hurlock, 2003).

Masa remaja ini merupakan
masalah tersulit dalam tahap perkembangan dikarenakan masa remaja merupakan masa pencarian identitas. Hubungan nyata antara kemiskinan dan permasalahan psikologis pada remaja yang tumbuh dalam kemiskinan memiliki risiko lebih tinggi menghadapi masalah-masalah psikologis (M. Iqbal, 2001:9). Oleh karena itu, dalam tahap ini remaja masih sangat labil sehingga banyak hal yang dapat mempengaruhi remaja dalam melakukan banyak hal.

Untuk dapat beradaptasi dengan kehidupan yang memiliki status sosial rendah di tengah zaman yang semakin modern dibutuhkan suatu kekuatan. Dalam hal ini merupakan kekuatan yang menuntut remaja untuk dapat bangkit 
dan keluar dari kenyataan bahwa hidup mereka tidak harus seperti remaja lain yang hidup mengikuti zaman akan tetapi dengan ekonomi yang rendah mereka tetap dapat hidup bahagia dan sukses seperti remaja lain yang hidup mengikuti tren masa kini. Kekuatan untuk tetap mampu bertahan dalam menghadapi, mengatasi, mempelajari kesulitan dalam hidup, dan bahkan ditransformasi oleh kesulitan tersebut dinamakan resiliensi (Grotberg, 2003).

Resiliensi adalah kemampuan untuk beradaptasi dan tetap teguh dalam situasi sulit (Reivich dan Shatte, 2002). Resiliensi merupakan faktor yang berperan penting untuk dapat bertahan dalam mengatasi masalah dan mempertahankan diri dalam situasi yang menekan, serta mampu beradaptasi dan belajar dalam situasi tersebut. Resiliensi sangat memberi pengaruh positif bagi individu karena resiliensi dapat mengubah kehidupan seseorang menjadi lebih baik dari sebelumnya. Individu yang dapat melakukan resiliensi dengan baik akan mampu mengatasi kesulitan dan trauma yang dihadapi.

Dalam mengembangkan resiliensi, banyak faktor yang dapat mempengaruhi salah satunya faktor lingkungan yang mencakup spiritualitas dan agama. Seseorang yang memiliki agama dan mendalaminya maka akan memiliki spiritualitas yang baik yang akan menjadi pengendali kehidupan manusia dan kedalam pembinaan pribadi yang jika tertanam kuat maka semakin kuat pengaruhnya dalam pengendalian tingkah laku dan pembentukan sikap. Seseorang yang memiliki spiritualitas dan mampu dalam menghadapi dan memecahkan masalah serta mampu untuk mengendalikan tingkah laku dan sikap maka orang tersebut akan dikatakan memiliki kecerdasan spiritual. Kemampuan dalam menghadapi dan memecahkan persoalan makna dan nilai, yaitu kecerdasan untuk menempatkan perilaku dan hidup dalam konteks makna yang lebih luas dan kaya, kecerdasan untuk menilai bahwa tindakan atau jalan hidup seseorang lebih bermakna disebut dengan kecerdasan spiritual (Zohar dan Marshal, 2007). King dan DeCicco (2009) menyatakan kecerdasan spiritual adalah sekumpulan kapasitas mental adaptif yang didasarkan pada aspek-aspek non material dan transenden dari realitas, secara khusus yang berhubungan dengan critical existential thingking, personal meaning production, transcendental awareness, conscious state expansion. Kecerdasan spiritual merupakan modal spiritual individu, dengan model spiritual yang ada dalam diri seseorang akan mampu membangkitkan motivasi tinggi dalam memandang kehidupan, tidak lagi hanya memandang sebatas materi tetapi menjadikan hidup ini penuh arti dan makna yang lebih tinggi.

\section{METODE}

Pendekatan yang digunakan dalam dalam penelitian ini adalah pendekatan kuantitatif. Variabel yang digunakan dalam penelitian ini yaitu Kecerdasan Spiritual dan Resiliensi. Penelitian ini dilakukan di Desa Jongin Kab. Tolitoli Sulawesi Tengah. Sampel dalam penelitian ini berjumlah 39 orang remaja yang berumur dari 12-21 tahun, tinggal di rumah yang kurang layak, dan masih sering mendapatkan bantuan.Metode yang digunakan dalam penelitian ini berupa skala yakni skala resiliensi dan skala kecerdasan spiritual dengan menggunakan metode skala Likert. Komponen skala resiliensi terdiri dari 7 aspek yaitu regulation emotion, impuls control, optimism, causal analysis, empathy, self eficcacy, danreaching out.Komponen skala kecerdasan spiritual terdiri dari critical existential thinking, personal meaning production, trancendental awareness dan conscious state expansion. 
Teknik Analisis yang digunakan dalam penelitian ini yaitu analisis korelasi dan regresi sederhana. Peneliti menggunakan analisis korelasi product moment dengan bantuan SPSS for windows versi 16 .

\section{HASIL}

Berdasarkan hasil perhitungan dan analisis data dengan menggunakan teknik korelasi product moment diperoleh hasil reliabilitas skala resiliensi Alpha's Cronbach 0,88 dan skala kecerdasan spiritual memiliki nilai Alpha's Cronbach sebesar 0,789. Nilai koefisien korelasi sebesar $\mathrm{r}=0,624(\mathrm{p}<$ 0.01 ) artinya ada hubungan yang sangat signifikan antara kecerdasan spiritual dengan resiliensi, semakin tinggi kecerdasan spiritual maka semakin tinggi pula resiliensi, dan sebaliknya. Selain itu, dalam penelitian ini kedua varibel yang digunakan juga berdistribusi normal dan juga kedua variable linear. Menurut American Psychological Assosiation (dalam Djudiyah, 2011) menyatakan bahwa cara pandang diri negatif terhadap diri sendiri serta perasaan tidak berharga pada diri remaja akan berdampak pada perkembangan resiliensinya. Apabila remaja menganggap bahwa hidup ini kejam hanya membuat dirinya menderita dan merasa tidak berdaya menghadapinya maka akan menyebabkan daya resiliensinya tidak berkembang atau cenderung rendah, namun bila remaja berusaha bangkit dari keterpurukannya serta berusaha menerima apa yang dimiliknya saat ini maka daya resiliensinya akan dapat berkembang.

Berdasarkan hasil uji korelasi, SQ memberikan pengaruh berdasarkan aspek-aspek yang dimilikinya, seperti aspek Critical thinking dapat menjadikan individu terampil konseptualisasi; menerapkan, menganalisa dan mengevalusai informasi yang dikumpulkan dari observasi, pengalaman, refleksi, penalaran atau komunikasi (King dan DeCicco, 2009). Individu yang mampu untuk bersikap dan berpikir kritis akan cenderung memiliki resiliensi yang tinggi. Begitu juga dengan aspek personal meaning production, pada aspek ini individu dapat menemukan makna hidup yang sebenarnya tanpa memandang pahit kehidupan yang sedang dijalani. Personal meaning dapat diartikan sebagai kemampuan memiliki tujuan dalam hidup, memiliki arah, ketertiban dan alasan keberadaan (Reker, dalam King dan DeCicco, 2009). Sehingga individu yang dalam hidupnya memiliki tujuan dan arah serta tidak memandang pahitnya suatu kehidupan dapat dikatakan memiliki resiliensi yang tinggi.

Begitu juga dengan aspek transcendental awareness, berdasarkan aspek ini, individu dapat memberikan kesuksesan pada dirinya karena individu mampu bergerak melalui batas-batas yang membatasi pribadi mereka dengan mengintegrasikan tujuan individu dengan tujuan yang lebih besar lagi (King dan DeCicco, 2009). Oleh karena itu, individu yang mampu melihat lebih luas bagaimana kehidupannya dan mampu untuk berjalan keluar dari "zona nyaman” berarti memiliki resiliensi yang tinggi. Sama halnya dengan aspek ke empat yaitu aspek conscious state expansion merupakan kemampuan individu untuk dapat masuk dan keluar kepada kesadaran spriritual yang lebih tinggi dan mampu merenungkan kehidupan yang sedang mereka jalani dan mampu mengambil makna dari kehidupan tersebut (King dan DeCicco, 2009). Individu yang mampu merenungkan kehidupan yang mereka jalani dan mampu dalam mengambil makna dalam kehidupannya akan cenderung memiliki resiliensi yang tinggi. 
Seseorang yang memiliki agama dan mendalaminya maka akan memiliki spiritualitas yang baik yang akan menjadi pengendali dalam kehidupan manusia dan seseorang yang memiliki spiritualitas dan mampu dalam menghadapi berbagai persoalan dan dapat mengendalikan tingkah laku disebut memiliki kecerdasan spiritual. Oleh karena itu semakin tinggi kecerdasan sesorang dalam menempatkan makna hidupnya maka semakin tinggi pula resiliensi seseorang.

\section{SIMPULAN}

Berdasarkan hasil penelitian yang dilakukan di Desa Jongin Kab. Tolitoli, Sulawesi Tengah tentang hubungan Kecerdasan Spiritual dengan Resiliensi, maka dapat ditarik kesimpulan bahwa terdapat hubungan positif antara kecerdasan spiritual dengan resiliensi pada remaja yang terlahir dalam keluarga miskin dengan $r=0,422$ $(\mathrm{p}<0,05)$. Maka semakin tinggi kecerdasan spiritual semakin tinggi juga resiliensi, dan sebaliknya.

Rekomendasi dari hasil penelitian ini adalah (1) Untuk remaja yang berada dalam keluarga miskin, agar bisa semakin mencerdaskan spiritualitas dalam diri masing-masing sehingga dapat semakin meningkatkan resiliensi. (2) Untuk penelitian selanjutnya dapat melihat hubungan resiliensi dengan faktor-faktor lain yang mempengaruhi seperti faktor biologis atau faktor personal dan juga dapat meneliti bagaimana caranya mengembangkan kecerdasan spiritual agar bisa meningkatkan resiliensi.

\section{DAFTAR PUSTAKA}

Almedom, A. M., \& Tumwine, J. K. (2008). Resilience to disasters: a paradigm shift from vulnerability to strength. African Health Sciences, 8 Suppl 1, S1-4. Retrieved from http://www.pubmedcentral.nih.go v/articlerender.fcgi?artid $=306072$ $4 \&$ tool=pmcentrez\&rendertype $=\mathrm{a}$ bstract

Azwar, S. (2012). Penyusunan Skala Psikologi. Yogyakarta: Pustaka Belajar.

Badan Pusat Statistik. (2018, 2 Januari). Presentase Penduduk Miskin September 2017 Mencapai10,12 Persen. Diperoleh 14 Februari 2018.

https://www.bps.go.id/pressreleas e/2018/01/02/1413/persentasependuduk-miskin-september2017-mencapai-10-12persen.html.

Block, J., \& Turula, E. (1963). Identification, Ego Control, and Adjustment. Child Development, 34(4), 945.

https://doi.org/10.2307/1126537

Cahyani, Y. E., \& Akmal, S. Z. (2017). Peranan Spiritualitas Terhadap Resiliensi Pada Mahasiswa Yang Sedang Mengerjakan Skripsi. Psikoislamedia: Jurnal Psikologi, 2(1), 32.

https://doi.org/10.22373/psikoisla media.v2i1.1822

Christensen, C. M., \& Overdorf, M. (2002). Disruptive Change. Harvard Business Review, 80(April), 94-101. https://doi.org/10.1002/rwm3.200 19

Connor, K. M., \& Davidson, J. R. T. (2003). Development of a new Resilience scale: The ConnorDavidson Resilience scale (CDRISC). Depression and Anxiety, 18(2), 76-82.

https://doi.org/10.1002/da.10113 
Hammouri, K. A., \& Abdulaziz A. S. (2016). Spiritual Intelligence and the Differences among Gifted and Non-gifted Students, According to Gender and Class Level. American Journal of Educational Research, 4(15), 1086-1095. https://doi.org/10.12691/education $-4-15-6$

Hurlock, EB. (2003). Psikologi Peerkembangan anak jilid 2. Jakarta: Erlangga.

Herrman, H., Stewart, D. E., DiazGranados, N., Berger, E. L., Jackson, B., \& Yuen, T. (2011). What is resilience? Canadian Journal of Psychiatry, 56(5), 258265.

https://doi.org/10.1177/07067437 1105600504

Holland, R. (2013). Educating Urban AtRisk Students on Aspect s of Life Skills and Personal Management While enrolled at Borough of Manhattan Community College. Journal of Chemical Information and Modeling, 53(9), 1689-1699.

https://doi.org/10.1017/CBO9781 107415324.004

Isdijoso, W., Suryahadi, A., \& Akhmadi. (2016). Penetapan Kriteria dan Variabel Pendataan Penduduk Miskin yang Komprehensif dalam Rangka Perlindungan Penduduk Miskin di Kabupaten / Kota. The SMERU Reaserch Institute. 1-25. http://www.smeru.or.id/sites/defa ult/files/publication/cbms_criteria _ind.pdf

Kalil, A. (2003). Family Resilience and Good Child Outcomes. A review of the literature. New Zealend: Ministry of Social Development. https://www.msd.govt.nz/docume nts/about-msd-and-ourwork/publicationsresources/archive/2003-family- resilience-good-child-

outcomes.doc

King, D. B., \& Decicco, T. L. (2009). A Viable Model and Self-Report Measure of Spiritual Intelligence. International Journal of Transpersonal Studies, 28(1), 6885.

Mawarpury, M. \& Mirza. (2017). Resilience in Family: Psychological Perspective. Jurnal Psikoislamedia, 2(April), 96-106.

Nay, T.O., \& Dewanti, R. (2013). Hubungan Kecerdasan Spiritual Dengan Resiliensi Pada Mahasiswa Yang Mengikuti Program Akselerasi. Jurnal Tabularasa. 8(2), 708-716.

Pasudewi, C. Y. (2012). Resiliensi Pada Remaja Binaan Bapas Ditinjau Dari Coping Stress. Journal of Sosial and Industrial Psychology, 2(1), 64-68.

Rahmasari, L. (2012). Pengaruh Kecerdasan Intelektual, Kecerdasan Emosi dan Kecerdasan Spiritual Terhadap Kinerja Karyawan. Majalah Ilmiah INFORMATIKA, 3(1), 120.

Reivich, A. K., \& Shatte. A. (2002). The Resilience Factor: 7 Keys to Finding Your Strength and Overcoming Life's Hurdles. Three Rivers press.

https://www.deeelliottconsulting.c om/system/files/The\%20Resilienc e\%20Factor.pdf

Rinaldi. (2010). Resiliensi pada masyarakat kota padang ditinjau dari jenis kelamin. Jurnal Psikologi, 3(2), 99-105.

Riza, M., \& Herdiana, I. (2013). Resiliensi pada Narapidana Lakilaki di Lapas Klas 1 Medaeng. Jurnal Psikologi Kepribadian Dan Sosial, 2(1), 1-6. 
Septiani, T., \& Fitria, N. (2016). Hubungan Antara Resiliensi Dengan Stres Pada Mahasiswa Sekolah Tinggi Kedinasan. Jurnal Penelitian Psikologi, 7(2), 59-76.

Setyowati, A., Hartati, S., \& Sawitri, D. R. (2010). Hubungan Antara Kecerdasan Emosional dengan Resiliensi Pada Siswa Penghuni Rumah Damai. Psikologi Undip, 7(1), 67-77.

Sina, P. G., \& Noya, A. (2012). Pengaruh Kecerdasan Spiritual Terhadap Pengelolaan Keuangan Pribadi. Jurnal Manajemen, 11(2), 171-188.

https://doi.org/10.28932/jmm.v11i 2.183

Sisca, H., \& Moningka, C. (2008). Resiliensi Perempuan Dewasa Muda Yang Pernah Mengalami Kekerasan Seksual Di Masa Kanak-Kanak. Jurnal Psikologi, 2(1), 61-69. Retrieved from http://www.ejournal.gunadarma.a c.id/index.php/psiko/article/viewF ile/245/186

Soetjinigsih, C. H. (2012). Perkembangan anak: Sejak Pembuahan Sampai Dengan Kanak-kanak Akhir. Jakarta: Prenada

Stapleford, F. N. (1919). Causes of Poverty. The Public Health Journal, 10(4), 157-161. Retrieved from http://www.jstor.org/stable/41975 717

Sugiyono, (2011). Metode penelitian administrasi. Bandung: Alfabeta

Sukmawati, N. L. G., Herawati, N. T., \& Sinarwati, N. K. (2014). Pengaruh etika profesi, kecerdasan intelektual, kecerdasan emosional, dan kecerdasan spiritual terhadap opini auditor. E-Journal SI Ak
Universitas Pendidikan Ganesha, 2(1) 1-11.

https://www.google.co.id/search? $\mathrm{q}=54-2484-1-S M$.pdf\&oq=54-

2484-1

SM.pdf\&aqs=chrome..69i57.968j $0 \mathrm{j} 4 \&$ sourceid $=$ chrome \&ie $=U T F-8$

Ulina, M. O., Kurniasih, O. I., \& Putri, D. E. (2013). Hubungan Religiusitas dengan Penerimaan Diri pada Masyarakat Miskin. Jurnal Proceeding PESAT, 5, 1722.

Uyun, Q. R. (2012). Sabar Dan Shalat Sebagai Model Untuk Meningkatkan Resiliensi di Daerah Bencana, Yogyakarta. Journal Psychology Intervention, 4(2), 253-267.

Yantiek, E. (2014). Kecerdasan emosi, kecerdasan spiritual dan perilaku prososial remaja. Persona, Jurnal Psikoloi Indonesia, 3(1), 22-31.

Zohar, M., \& Marshall, I. (2000). Spiritual Intelligence, The Ultimate Intelligence. London: Bloomsburry Publishing, Inc. https://books.google.co.id/books?i $\mathrm{d}=$ bfhSGrIm7KIC\&printsec $=$ front cover\&hl=id\&source=gbs_ge_su mmary_r\&cad $=0 \# v=$ onepage $\& q \&$ $\mathrm{f}=$ false

Guilford, J.P. (1956). Fundamental Statistics in Psychology and Education. (p. 145). New York: McGraw Hill.

https://books.google.co.id/books?i $\mathrm{d}=$ fbWeqTuQUwgC\&q=Fundame ntal+Statistics+in+Psychology+an $\mathrm{d}+$ Education\&dq=Fundamental $+S$ tatistics+in+Psychology+and+Edu cation\&hl=en\&sa $=$ X\&ved $=0 \mathrm{ahU}$ KEwja4OnWvfvaAhXBvLwKHd L4D9oQ6AEIJzAA 